\title{
A simple and efficient method for the preparation of 5-hydroxy-3-acyltetramic acids
}

\author{
Johanna Trenner and Evgeny V. Prusov*
}

\author{
Letter \\ Address: \\ Department of Medicinal Chemistry, Helmholtz Centre for Infection \\ Research, Inhoffenstr. 7, 38124 Braunschweig, Germany \\ Email: \\ Evgeny V. Prusov* - evgeny.prusov@helmholtz-hzi.de \\ * Corresponding author \\ Keywords: \\ heterocyclic chemistry; hydroxylation; natural products; tetramic acids
}

\author{
Beilstein J. Org. Chem. 2015, 11, 323-327. \\ doi:10.3762/bjoc. 11.37 \\ Received: 06 January 2015 \\ Accepted: 20 February 2015 \\ Published: 06 March 2015 \\ Associate Editor: R. Sarpong \\ (c) 2015 Trenner and Prusov; licensee Beilstein-Institut. \\ License and terms: see end of document.
}

\begin{abstract}
Oxidation of the bisenolates of 3-acyltetramic acid to the corresponding 5-hydroxylated compounds using molecular oxygen is reported. The deprotection of the resulting compounds was also achieved.
\end{abstract}

\section{Findings}

5-Hydroxy-3-acyltetramic acid is an unusual structural element which is found in the molecules of such biologically active natural products as delaminomycin A [1], embellicin A [2] and integramycin [3] (Figure 1).

Additionally, 5-heterosubstituted-3-acyltetramic acids were recently identified by Moloney as perspective lead structures for the development of novel antibacterial compounds [4]. Intrigued by their potential antibiotic properties, we were interested to investigate their activities in various assays but the literature survey showed that synthetic approaches to 5-hydroxylated 3-acyltetramic acids are essentially non-existent, although M. Coster reported the synthesis of 5-hydroxytetramic acid ethers by chemoselective reduction of the corresponding maleimides [5] and oxidation of pyrrolinones was reported by Clayden [6]. Therefore, we decided to develop a simple method to produce these interesting compounds.
At first we prepared three nitrogen-protected 3-acyltetramic acids (7-9) according to the Matsuo [7] variant of Lacey-Dieckmann [8] condensation (Scheme 1) [9,10]. Reaction of either $\beta$-ketoester 4 or Meldrum's acid derivative 9 with suitably protected glycine esters $(\mathbf{5 , 6 , 1 0})$, followed by baseinduced condensation furnished the desired tetramic acid model compounds as crystalline solids after treatment with a small quantity of methanol. Alternatively, purification of these compounds can be readily achieved by preparative HPLC, whereas all attempts to perform the standard flash column chromatography on silica gel or aluminum oxide resulted in complete decomposition of the material.

With the substrates in hands, we initially investigated the use of Davis oxaziridine chemistry (Table 1, entries 1 and 2) [11]. Deprotonation of 7 with an excess of LDA followed by treatment of the resulting bisenolate with camphoryl-based oxaziri- 


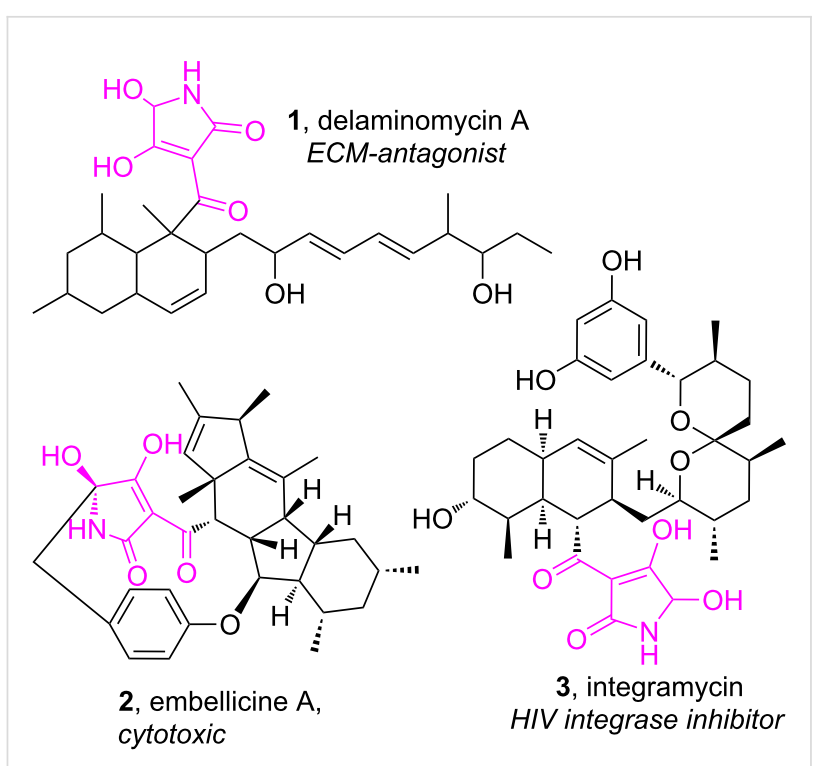

Figure 1: Naturally occurring 5-hydroxylated 3-acyltetramic acids.

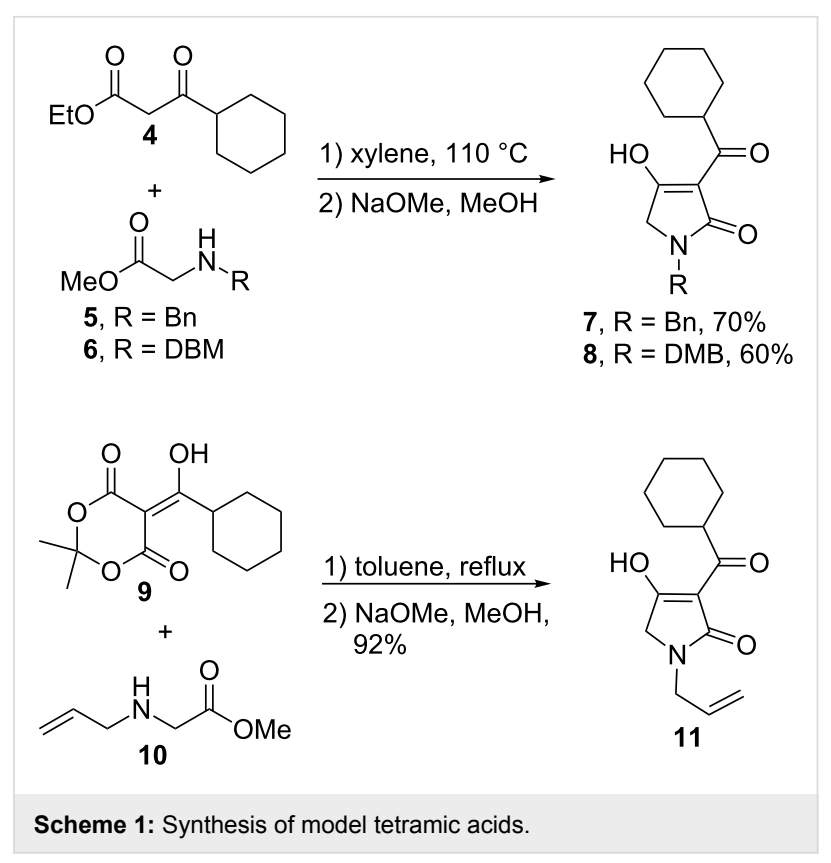

Our efforts to improve the yield of the desired product by variation of reaction conditions were rather fruitless, and therefore, our attention was turned to the alternative oxidation of enolates with molecular oxygen in the presence of triethyl phosphite as originally described by Hartwig [12-15]. Application of these conditions resulted in a clean conversion to the 5-hydroxy-3acyltetramic acid but again, the isolated yield of the product was rather moderate. Switching to KHMDS as a base dramatically increased the yield and with further optimization of the

Table 1: Initial study of oxidation of tetramic acid 7.<smiles>O=C(C1=C(O)CN(Cc2ccccc2)C1=O)C1CCCCC1</smiles>

7

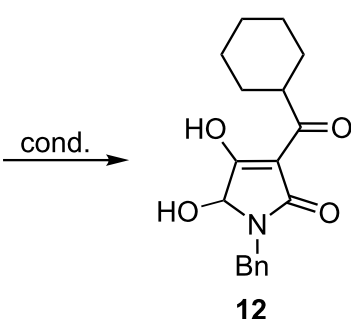

12<smiles>CC1(C)CC2(C)CCC(N1O)C2(C)C</smiles>

13, Davis reagent I<smiles>O=S(=O)(c1ccccc1)N1OC1c1ccccc1</smiles>

14 , Davis reagent II<smiles>O=C(C1=C(O)C(C(NS(=O)(=O)c2ccccc2)c2ccccc2)N(Br)C1=O)C1CCCCC1</smiles>

\begin{tabular}{|c|c|c|c|c|}
\hline entry & base & solvent & reagent, $T, t$ & yield \\
\hline 1 & LDA ( 2.5 equiv) & THF & Davis reagent $\mathrm{I}, \mathbf{1 3}$ (1.5 equiv), $2 \mathrm{~h},-78^{\circ} \mathrm{C}$ & $27 \%$ \\
\hline 2 & LDA ( 2.5 equiv) & THF & Davis reagent II, 14 ( 1.5 equiv), $30 \mathrm{~min},-78^{\circ} \mathrm{C}$ & $28 \%{ }^{a}$ \\
\hline 3 & LDA ( 2.5 equiv) & THF & $(\mathrm{BzO})_{2}\left(1.5\right.$ equiv), $1.5 \mathrm{~h},-78^{\circ} \mathrm{C}$ & $1 \%$ \\
\hline 4 & LDA (2.5 equiv) & THF & $t$-BuOOBz (1.5 equiv), $1.5 \mathrm{~h},-78^{\circ} \mathrm{C}$ & $8 \% \mathrm{~b}$ \\
\hline 5 & LDA (2.5 equiv) & THF & $(t-\mathrm{BuO})_{2}(1.5$ equiv $), 1.5 \mathrm{~h},-78^{\circ} \mathrm{C}$ & $0 \%$ \\
\hline 6 & - & $\mathrm{H}_{2} \mathrm{O}$ & $\mathrm{O}_{2}, \mathrm{rt}, 14 \mathrm{~d}$ & $0 \%$ \\
\hline 7 & - & $\mathrm{MeOH} / \mathrm{H}_{2} \mathrm{O}$ & Oxone $^{\circledR}, \mathrm{rt}, 1 \mathrm{~d}$ & $0 \%$ \\
\hline
\end{tabular}

a $15 \%$ of 15 were also isolated. ${ }^{b}$ Yield of benzoate derivative. 
reaction time and dilution a 78\% yield (brsm) of the hydroxylated compound was achieved (Table 2). Discoloration of the bisenolate solution was usually observed within 5 minutes and the reaction was essentially complete in 20 minutes according to TLC analysis. Oxidation reactions performed in polar aprotic solvents, such as DMPU and DMF, gave significantly lower yields compared to THF. As with the parent tetramic acids, isolation and purification of the hydroxylated derivatives was only possible by means of preparative HPLC.

Table 2: Condition optimization for hydroxylation of tetramic acid 7.<smiles>O=C(C1=C(O)CN(Br)C1=O)C1CCCCC1</smiles>

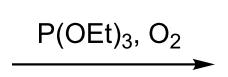

7

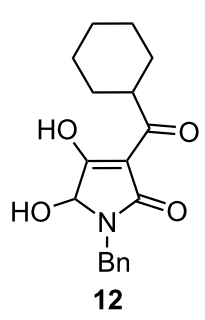

\begin{tabular}{lllll}
\hline entry & base & solvent & $t, T$ & yield $^{\mathrm{a}}$ \\
\hline 1 & LDA & THF & $30 \mathrm{~min},-78{ }^{\circ} \mathrm{C}$ & $27 \%$ \\
2 & KOt-Bu & THF & $\begin{array}{l}3 \mathrm{~h},-78^{\circ} \mathrm{C} ; \\
14 \mathrm{~h}, \mathrm{rt}\end{array}$ & $10 \%(14 \%)$ \\
3 & LiHMDS & THF & $2 \mathrm{~h},-78{ }^{\circ} \mathrm{C}$ & $51 \%(59 \%)$ \\
4 & NaHMDS & THF & $2 \mathrm{~h},-78{ }^{\circ} \mathrm{C}$ & $44 \%(51 \%)$ \\
5 & KHMDS & THF & $35 \mathrm{~min},-78{ }^{\circ} \mathrm{C}$ & $74 \%(77 \%)$ \\
6 & KHMDS & THF & $10 \mathrm{~min},-78{ }^{\circ} \mathrm{C}$ & $72 \%(78 \%)$ \\
7 & KHMDS & DME & $2 \mathrm{~h} 15 \mathrm{~min}$, & $11 \%(18 \%)$ \\
8 & KHMDS & DMPU & $1 \mathrm{~h} 15 \mathrm{~min}$, & $20 \%(36 \%)$ \\
& & & $-78{ }^{\circ} \mathrm{C}$ & \\
9 & KHMDS & DMF & $2 \mathrm{~h},-78{ }^{\circ} \mathrm{C}$ & $32 \%(48 \%)$ \\
\hline
\end{tabular}

aYields in parentheses are based upon recovered starting material.

Similar results were obtained for the $N$-DMB and $N$-allyl protected tetramic acids, though the best yield of compound $\mathbf{1 6}$ was obtained when LDA was employed as a base (Table 3 ).

The obtained hydroxylated tetramic acids can readily be transformed to hemiaminal ethers by simple heating them with the corresponding alcohol (Scheme 2). Etherification with methanol, ethanol and 2-trimethylsilylethanol produced the hemiaminal ethers in almost quantitative yields. We next investigated the deprotection of the so obtained hydroxylated derivatives. Several attempts to remove the benzyl group under various catalytic hydrogenation conditions failed entirely. Cleavage of the DMB group with TFA [16] was also tried, but brought no success and extensive formation of polymerization products of the corresponding iminium ion was observed. Oxidative cleavage of the DMB group with CAN [17] produced
Table 3: Oxidation of tetramic acids 8 and 11.<smiles>[R]N1CC(O)=C(C(=O)C2CCCCC2)C1=O</smiles>

8, $\mathrm{R}=\mathrm{DMB}$ 11, $\mathrm{R}=\mathrm{C}_{3} \mathrm{H}_{5}$

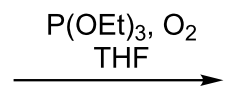<smiles>[R]N1C(=O)C(C(=O)C2CCCCC2)=C(O)C1O</smiles>

16, $\mathrm{R}=\mathrm{DMB}$

17, $\mathrm{R}=\mathrm{C}_{3} \mathrm{H}_{5}$

\begin{tabular}{lllll}
\hline entry & comp. & base & $t, T$ & yield $^{\mathrm{a}}$ \\
\hline 1 & $\mathbf{8}$ & $\mathrm{KHMDS}$ & $10 \mathrm{~min},-78{ }^{\circ} \mathrm{C}$ & $49 \%(61 \%)$ \\
2 & $\mathbf{8}$ & $\mathrm{KHMDS}$ & $25 \mathrm{~min},-78^{\circ} \mathrm{C}$ & $55 \%(69 \%)$ \\
3 & $\mathbf{8}$ & $\mathrm{KHMDS}$ & $40 \mathrm{~min},-78{ }^{\circ} \mathrm{C}$ & $62 \%(69 \%)$ \\
4 & $\mathbf{8}$ & $\mathrm{LDA}$ & $5 \mathrm{~min},-78^{\circ} \mathrm{C}$ & $47 \%(55 \%)$ \\
5 & $\mathbf{8}$ & $\mathrm{LDA}$ & $5 \mathrm{~min},-78^{\circ} \mathrm{C}$ & $56 \%(62 \%)$ \\
6 & $\mathbf{1 1}$ & $\mathrm{KHMDS}$ & $4 \mathrm{~h},-78^{\circ} \mathrm{C}$ to rt & $42 \%(44 \%)$ \\
\hline \multicolumn{5}{c}{ aYields in parentheses are based upon recovered starting material. }
\end{tabular}

no product either. Successful removal of the DMB-protecting group from hydroxylated tetramic acid $\mathbf{1 6}$ and (trimethylsilyl)ethyl hemiaminal 19 was achieved upon treatment with an excess of DDQ in wet DCM. Treatment of the $N$-allyl-protected compound using catalytic amounts of Pd trifluoroacetate/dppp [18] gave no conversion.

In summary, we have developed a simple and efficient method for the synthesis of 5-hydroxy-3-acyltetramic acids by oxidation of the corresponding bisenolates with molecular oxygen. We have also investigated the cleavage of various protecting groups from the nitrogen of tetramic acids. Application of this methodology to a broader scope of substrates as well as to the total synthesis of natural products is currently underway in our laboratory and will be reported in due course.

\section{Experimental}

General procedure for the oxidation of tetramic acids: Under an argon atmosphere, KHMDS (1 M in THF, 2.5 equiv) was added at $-78{ }^{\circ} \mathrm{C}$ to a solution of 3-cyclohexancarbonyltetramic acid (1.0 equiv) in dry $\operatorname{THF}(0.2 \mathrm{M})$ and stirred for $25 \mathrm{~min}$. After the addition of $\mathrm{P}(\mathrm{OEt})_{3}$ (2.0 equiv), oxygen from rubber balloon (predried by passing through a tube filled with $\mathrm{P}_{4} \mathrm{O}_{10}$ ) was passed through the bright yellow reaction mixture until full conversion (decolorizing and TLC control). Saturated $\mathrm{NH}_{4} \mathrm{Cl}$ solution $(3 \mathrm{~mL}$ ) was added and the reaction mixture was extracted with EtOAc. After evaporation of the solvent the residue was extracted with $\mathrm{SPE}\left(\mathrm{H}_{2} \mathrm{O}\right.$, then $\left.\mathrm{MeCN}\right)$ and the organic phase was purified with preparative HPLC (Machery Nagel, Nucleodur VP250/21 C18 Gravity, $5 \mu \mathrm{m} ; 280 \mathrm{~nm}$; 


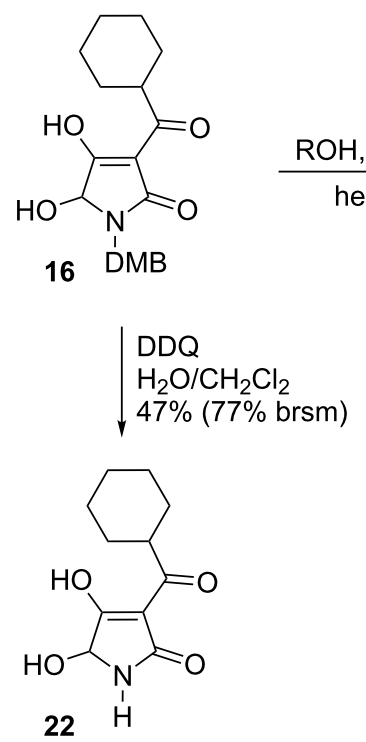<smiles>[R9]OC1C(O)=C(C(=O)C2CCCCC2)C(=O)N1[13CH3]</smiles>

18, $R=M e, 95 \%$

19, $\mathrm{R}=\mathrm{Et}, 92 \%$

20, $R=$ TMSE, $92 \%$

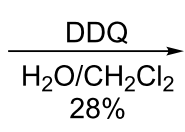

$28 \%$<smiles>[R6]C1NC(=O)C(C(=O)C2CCCCC2)=C1O</smiles>

21, $R=$ TMSE

Scheme 2: Synthesis of hemiaminal ethers and deprotection of the tetramic acids.

$90: 10 \mathrm{MeCN} /\left(\mathrm{H}_{2} \mathrm{O}+1 \%\right.$ formic acid $\left.) ; 10 \mathrm{~mL} / \mathrm{min}\right)$ to give the corresponding 5-hydroxy-3-cyclohexanecarbonyl tetramic acid as a white solid.

\section{Supporting Information}

\section{Supporting Information File 1}

Experimental procedures.

[http://www.beilstein-journals.org/bjoc/content/ supplementary/1860-5397-11-37-S1.pdf]

\section{Supporting Information File 2}

Copies of NMR spectra.

[http://www.beilstein-journals.org/bjoc/content/ supplementary/1860-5397-11-37-S2.pdf]

\section{Acknowledgements}

We are indebted to Prof. Dr. M. Kalesse for many helpful discussions. Financial support from DFG (grant PR-1328/3-1 to P. E. V) is greatly acknowledged.

\section{References}

1. Ueno, M.; Someno, T.; Sawa, R.; linuma, H.; Naganawa, $H_{\text {.; }}$ Ishizuka, M.; Takeuchi, T. J. Antibiot. 1993, 46, 979-984. doi:10.7164/antibiotics.46.979

2. Ebrahim, W.; Aly, A. H.; Wray, V.; Mándi, A.; Teiten, M.-H.; Gaascht, F.; Orlikova, B.; Kassack, M. U.; Lin, W.; Diederich, M.; Kurtán, T.; Debbab, A.; Proksch, P. J. Med. Chem. 2013, 56, 2991-2999. doi:10.1021/jm400034b
3. Singh, S. B.; Zink, D. L.; Heimbach, B.; Genilloud, O.; Teran, A.; Silverman, K. C.; Lingham, R. B.; Felock, P.; Hazuda, D. J. Org. Lett. 2002, 4, 1123-1126. doi:10.1021/ol025539b

4. Jeong, Y.-C.; Anwar, M.; Bikadi, Z.; Hazai, E.; Moloney, M. G. Chem. Sci. 2013, 4, 1008-1015. doi:10.1039/c2sc21713a

5. Issa, F.; Fischer, J.; Turner, P.; Coster, M. J. J. Org. Chem. 2006, 71, 4703-4705. doi:10.1021/jo0605750

6. Clayden, J.; Turnbull, R.; Pinto, I. Tetrahedron: Asymmetry 2005, 16, 2235-2241. doi:10.1016/j.tetasy.2005.05.042

7. Matsuo, K.; Kimura, M.; Kinuta, T.; Takai, N.; Tanaka, K. Chem. Pharm. Bull. 1984, 32, 4197-4204. doi:10.1248/cpb.32.4197

8. Lacey, R. N. J. Chem. Soc. 1954, 850-854 doi:10.1039/JR9540000850

9. Royles, B. J. L. Chem. Rev. 1995, 95, 1981-2001. doi:10.1021/cr00038a009

10. Schobert, R.; Schlenk, A. Bioorg. Med. Chem. 2008, 16, 4203-4221. doi:10.1016/j.bmc.2008.02.069

11. Davis, F. A.; Sheppard, A. C. Tetrahedron 1989, 45, 5703-5742. doi:10.1016/S0040-4020(01)89102-X

12. Hartwig, W.; Born, L. J. Org. Chem. 1987, 52, 4352-4358. doi:10.1021/jo00228a037

13. Chen, B.-C.; Zhou, P.; Davis, F. A.; Ciganek, E. $\alpha$-Hydroxylation of Enolates and Silyl Enol Ethers; Organic Reactions, Vol. 62; John Wiley \& Sons, Inc., 2003; pp 1-356. doi:10.1002/0471264180.or062.01

14. Rath, J.-P.; Kinast, S.; Maier, M. E. Org. Lett. 2005, 7, 3089-3092. doi:10.1021/ol0511068

15. Snyder, S. A.; Corey, E. J. J. Am. Chem. Soc. 2006, 128, 740-742. doi:10.1021/ja0576379

16. Shimshock, S. J.; Waltermire, R. E.; DeShong, P. J. Am. Chem. Soc. 1991, 113, 8791-8796. doi:10.1021/ja00023a029

17. Hashiguchi, S.; Natsugari, H.; Ochiai, M. J. Chem. Soc., Perkin Trans. 1 1988, 2345-2352. doi:10.1039/p19880002345

18. Cadierno, V.; Gimeno, J.; Nebra, N. Chem. - Eur. J. 2007, 13, 6590-6594. doi:10.1002/chem.200700477 


\section{License and Terms}

This is an Open Access article under the terms of the Creative Commons Attribution License

(http://creativecommons.org/licenses/by/2.0), which permits unrestricted use, distribution, and reproduction in any medium, provided the original work is properly cited.

The license is subject to the Beilstein Journal of Organic Chemistry terms and conditions:

(http://www.beilstein-journals.org/bjoc)

The definitive version of this article is the electronic one which can be found at:

doi:10.3762/bjoc. 11.37 